\title{
APPROACHING A CONCEPT FOR SOCIETAL RESPONSIBILITY IN ENGINEERING EDUCATION
}

\author{
Rein Terje THORSTENSEN, Anders FOLKMAN and Paul Ragnar SVENNEVIG \\ University of Agder, Norway
}

\begin{abstract}
Universities are major contributors to societal development, through the formation of aspiring young professionals. In addition to having responsibility for equipping these young professionals with knowledge and skills necessary for becoming attractive participants in working life, universities have responsibility for forming a society in responsible and ethical directions.

The authors of this paper also published a paper on a closely related subject at the E\&PDE 2018. In that paper, the concept of University Societal Responsibility (USR) was discussed through a practical case on cooperation between university and industry.

Discussing the existence and content of USR, the present paper investigates whether there are more appropriate ways than others to convey ethics to the engineering students, including developing an understanding of the USR through teaching.

This paper is a theoretical extension of the former paper, now discussing the foundation for conceptualising the topic. The conclusion represents an understanding of the concept, presented through a discussed model on how to implement the University Societal Responsibility in engineering education.
\end{abstract}

Keywords: University societal responsibility (USR), engineering education, engineering ethics, professional code of ethics for engineers

\section{INTRODUCTION}

Do universities have a societal responsibility? And if yes; how should this influence the way engineers are educated?

The first question was discussed in a paper for E\&PDE 2018 [1]. The conclusion is clear; it is claimed that both the legal system and ethical norms confirm the existence of a "University Society Responsibility" (USR).

It is suggested to compose an understanding of the content of USR corresponding to the well-established "Corporate Societal Responsibility" (CSR) of business life. A model is constructed, where the USR consists of four units which are interdependent in the way that they are neither cumulative nor additive - however, they should all be met simultaneously (figure 1). The relative size of the units in the model indicates the magnitude amongst them. The relative magnitude is claimed to vary over time, as a function of societal development.

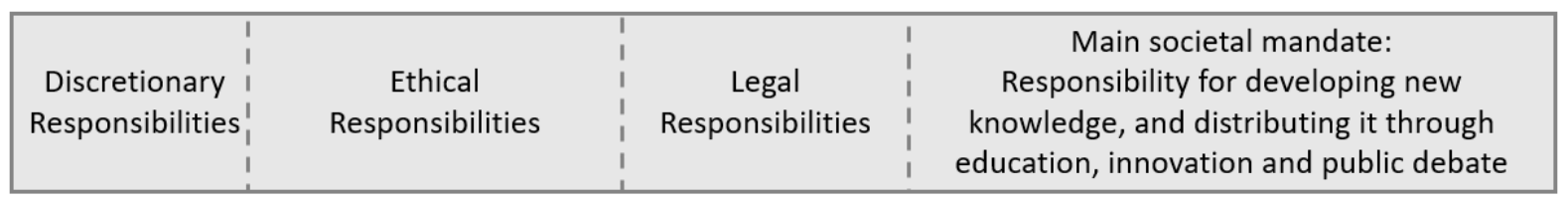

Figure 1. Suggestion for conceptualising "University Societal Responsibility" (USR) comprising four areas [1]

The unit "Main societal mandate" pinpoints that developing and distributing knowledge is the reason for the existence of the universities. All units except the far left (Discretionary responsibilities) includes HOW this should be executed, considering both codified and uncodified "rules". The far-left unit Discretionary responsibilities - is defined to represent issues that are "volitional and often tending to be philanthropic". Though the latter issue is the one most often brought to mind when discussing societal 
responsibility, it does not represent the main societal mandate of universities and is only indirectly handled in the present paper. Focus is on the remaining three.

The scope of this paper is to discuss how the existence of a University Societal Responsibility might influence and be expressed through education of engineers.

\section{ETHICS - THE PATHWAY TO RESPONSIBILITY}

As all four units in the USR model presented in Figure 1 include the word "responsibilities", all activities at universities - also engineering education - should have something to do with responsibility, for the university to fulfil its societal mandate.

An educated engineer should not only possess technical skills but also skills on how to execute the profession. Even these skills must be learned. But how can these skills be identified? The art of executing any profession might be focused on responsibility. Bucciarelli claims that "In engineering practice, value judgments are made all the time, often not explicitly - about the user, about robustness, about quality, about responsibilities, safety, societal benefit, risks and cost"[2]. All these "value judgments" represents responsibilities in the execution of the engineering profession, even if Bucciarelli emphasises responsibilities as a specific term amongst the others. Value judgments are assumed vital for the execution of the engineering profession.

How, then, do universities educate young professionals to execute value judgments? Ability to executing value judgments requires two things: 1) knowledge of ethical standards and 2) personal moral or ballast. The term "knowledge of ethical standards" claims the existence of some kind of "standard of conduct". Supposing the existence of such for any profession, knowledge of this obviously can be taught. The other term - personal moral or ballast - can hardly be taught but can be developed through training.

Ethics is included in several classical university educations. Most obvious is the references to the Hippocratic oath in medical education. However, also law and several other university programmes include ethical issues. In the education of lawyers in Norway, ethics forms an integral part of the education through a compulsory pre-course, followed up by compulsory ethics education at the professional level. Doctors have the same and additional requirements both during and after the study. For engineering education, ethical content is not obvious. Questions are: should it be? And in that case; how?

\section{IS THERE SUCH A THING AS "ENGINEERING ETHICS"?}

Engineering is profound to modern societies, and the physical results of engineering have the potential for implying damage and death to individuals, groups of people, and whole societies. References are easily made to civil engineering structures like dams for irrigation, water supply, and hydro powerplants; having potential by failure for wiping out the existence of whole cities. This profession needs ethical standards of conduct. But do they exist, and what are they?

Harris et al. claim that "By professional ethics, we refer to those special morally permissible standards of conduct that, ideally, every member of a profession wants every other member to follow, even if that would mean having to do the same. Ethics applies to members of a group simply because they are members of that group"[3].

In our rigid society, a lot of "standards of conduct" for the engineering profession is codified into formal regulations - in Europe typically illustrated by the Euro Norm system (EN) and the Construction Product Directive (CPD, for civil and structural engineering).

However, lots of dilemmas where engineers must execute value judgments are still not covered by codified regulations. People have feelings on "right and wrong" also for dilemmas that are not governed by any formal regulations. The ability for choosing right from wrong in these cases might be explained by "tacit knowledge" (contrasting "codified knowledge") - that is capabilities of choosing right based on individual integrity. These capabilities are, to a large degree, trained through practice. If not trained through education at university, development of the necessary competence to handle value judgment issues are left to random superiors that each newly educated engineer meets in the early years of his or her professional career.

\subsection{Professional code of ethics for engineers}

Do we have any tools or guidelines for developing the necessary tacit knowledge or ballast, preparing young engineers for all the coming value judgment they will have to handle - according to professional ethics? 
Multiple engineering societies have developed guidelines for the conduct of the profession. These ethical guidelines strive to be independent of special situations, hence defining "rules" for development of ethical ballast, rather than being situation dependent. Though engineering societies tend to be national, professions are not, and national societies seem to be internationally inspired. This is illustrated in table 1 , where the "codes of ethics" for civil engineers from engineering societies in three different countries are compared.

Table 1. Comparison of three professional codes of conduct for (civil) engineers

\begin{tabular}{|c|c|c|}
\hline Britain: ICE & USA: ASCE & Engineers Canada \\
\hline $\begin{array}{l}\text { 1. All members shall discharge } \\
\text { their professional duties with } \\
\text { integrity and shall behave with } \\
\text { integrity in relation to all } \\
\text { conduct bearing upon the } \\
\text { standing, reputation and dignity } \\
\text { of the Institution and of the } \\
\text { profession of civil engineering. }\end{array}$ & $\begin{array}{l}\text { 4. Act as a faithful agent } \\
\text { Engineers shall act in } \\
\text { professional matters for each } \\
\text { employer or client as faithful } \\
\text { agents or trustees and shall } \\
\text { avoid conflicts of interest. } \\
\text { 3. Issue true statements } \\
\text { Engineers shall issue public } \\
\text { statements only in an objective } \\
\text { and truthful manner. } \\
\text { 5. Reputation by merit } \\
\text { Engineers shall build their } \\
\text { professional reputation on the } \\
\text { merit of their services and shall } \\
\text { not compete unfairly with } \\
\text { others. }\end{array}$ & $\begin{array}{l}\text { 3. Act as faithful agents of their } \\
\text { clients or employers, maintain } \\
\text { confidentiality and avoid } \\
\text { conflicts of interest, but, where } \\
\text { such conflict arises, fully } \\
\text { disclose the circumstances } \\
\text { without delay to the employer } \\
\text { or client. } \\
\text { 6. Present clearly to employers } \\
\text { and clients the possible } \\
\text { consequences if engineering } \\
\text { decisions or judgments are } \\
\text { overruled or disregarded. }\end{array}$ \\
\hline $\begin{array}{l}\text { 2. All members shall only } \\
\text { undertake work that they are } \\
\text { competent to do. }\end{array}$ & $\begin{array}{l}\text { 2. Service with competence } \\
\text { Engineers shall perform } \\
\text { services only in areas of their } \\
\text { competence. }\end{array}$ & $\begin{array}{l}\text { 2. Offer services, advise on or } \\
\text { undertake engineering } \\
\text { assignments only in areas of } \\
\text { their competence and practise } \\
\text { in a careful and diligent manner } \\
\text { and in compliance with } \\
\text { applicable legislation. }\end{array}$ \\
\hline $\begin{array}{l}\text { 3. All members shall have full } \\
\text { regard for the public interest, } \\
\text { particularly in relation to } \\
\text { matters of health and safety, } \\
\text { and in relation to the well- } \\
\text { being of future generations. } \\
\text { 4. All members shall show due } \\
\text { regard for the environment and } \\
\text { for the sustainable management } \\
\text { of natural resources. }\end{array}$ & $\begin{array}{l}\text { 1. Hold safety paramount } \\
\text { Engineers shall hold paramount } \\
\text { the safety, health and welfare } \\
\text { of the public and shall strive to } \\
\text { comply with the principles of } \\
\text { sustainable development in the } \\
\text { performance of their } \\
\text { professional duties. }\end{array}$ & $\begin{array}{l}\text { 1. Hold paramount the safety, } \\
\text { health and welfare of the public } \\
\text { and the protection of the } \\
\text { environment and promote } \\
\text { health and safety within the } \\
\text { workplace. } \\
\text { 8. Be aware of and ensure that } \\
\text { clients and employers are made } \\
\text { aware of, societal and } \\
\text { environmental consequences of } \\
\text { actions or projects and } \\
\text { endeavour to interpret } \\
\text { engineering issues to the public } \\
\text { in an objective and truthful } \\
\text { manner. }\end{array}$ \\
\hline $\begin{array}{l}\text { 5. All members shall develop } \\
\text { their professional knowledge, } \\
\text { skills and competence on a } \\
\text { continuing basis and shall give }\end{array}$ & $\begin{array}{l}\text { 7. Continue professional } \\
\text { development } \\
\text { Engineers shall continue their } \\
\text { professional development }\end{array}$ & $\begin{array}{l}\text { 4. Keep themselves informed } \\
\text { in order to maintain their } \\
\text { competence and strive to }\end{array}$ \\
\hline
\end{tabular}




\begin{tabular}{|c|c|c|}
\hline $\begin{array}{l}\text { all reasonable assistance to } \\
\text { further the education, training } \\
\text { and continuing professional } \\
\text { development of others. }\end{array}$ & $\begin{array}{l}\text { throughout their careers and } \\
\text { shall provide opportunities for } \\
\text { the professional development } \\
\text { of those engineers under their } \\
\text { supervision. }\end{array}$ & $\begin{array}{l}\text { advance the body of knowledge } \\
\text { within which they practise. }\end{array}$ \\
\hline $\begin{array}{l}\text { 6. All members shall: } \\
\text { (Followed by } 5 \text { bullet points on } \\
\text { obligation to notify the society } \\
\text { on compromisation or violation } \\
\text { and supporting colleagues in } \\
\text { doing so.) }\end{array}$ & $\begin{array}{l}\text { 6. Uphold professional } \\
\text { honour } \\
\text { Engineers shall act in such a } \\
\text { manner as to uphold and } \\
\text { enhance the honour, integrity, } \\
\text { and dignity of the engineering } \\
\text { profession and shall act with } \\
\text { zero tolerance for bribery, } \\
\text { fraud, and corruption. } \\
\text { 8. Treat all persons fairly } \\
\text { Engineers shall, in all matters } \\
\text { related to their profession, treat } \\
\text { all persons fairly and } \\
\text { encourage equitable } \\
\text { participation without regard to } \\
\text { gender or gender identity, race, } \\
\text { national origin, ethnicity, } \\
\text { religion, age, sexual } \\
\text { orientation, disability, political } \\
\text { affiliation, or family, marital, } \\
\text { or economic status. }\end{array}$ & $\begin{array}{l}\text { 10. Uphold and enhance the } \\
\text { honour and dignity of the } \\
\text { profession. } \\
\text { 5. Conduct themselves with } \\
\text { integrity, equity, fairness, } \\
\text { courtesy and good faith } \\
\text { towards clients, colleagues and } \\
\text { others, give credit where it is } \\
\text { due, and accept, as well as } \\
\text { give, honest and fair } \\
\text { professional criticism. } \\
\text { 7. Report to their regulator } \\
\text { other appropriate agencies any } \\
\text { illegal or unethical engineering } \\
\text { decisions or practices by } \\
\text { registrants or others. } \\
\text { 9. Treat equitably and promote } \\
\text { the equitable and dignified } \\
\text { treatment of people in } \\
\text { accordance with human rights } \\
\text { legislation. }\end{array}$ \\
\hline
\end{tabular}

The British "Code of Conduct" from the Institute of Civil Engineers (ICE) is used for reference (left column). The relatives from USA (American Society for Civil Engineers, ASCE) and Engineers Canada are tentatively sorted to correspond with the ICE categorisation. The original numbering for ASCE and Engineers Canada is kept, for true reference to the source. The categorisation is not completely overlapping. It is clear that the codes of conduct from the three different national societies are closely related, and either one can act as guidelines for "Professional code of ethics for engineers" at any engineering education. (Examples are taken from civil engineering; however, corresponding codes are available for all engineering professions.) Original headlines in bold text for the ASCE code is kept in the table, as it represents a typical summary of the content.

\section{HOW SHOULD ETHICS BE TAUGHT?}

In an extensive survey in and around Stanford University, McGinn [4] found that practicing engineers felt poorly prepared from university for meeting the ethical issues they met in working life. This respondent group also had deeply divergent views on what is "the most important non-technical aspect of being an ethical and socially responsible engineering professional". Hence, engineers express lack of ballast from education. Further, the deeply divergent view might be understood by the lack of basic educational perspective.

Amongst the respondent group of Stanford engineering students, McGinn found that "Substantial, latent divergence of opinion exists about what makes an issue an ethical issue, something that fuels the tendency to fall back on either facile ethical relativism or traditional moral intuition uninformed by contemporary engineering realities." He concludes that there is a substantial mismatch between engineering students' expectation and practicing engineers' experience regarding ethics and that both groups are weakly equipped with ethical knowledge, skills and perspective. Though originating from another country and some years ago, we assume this situation still to be representative today.

There are (at least) two discussions on how ethics should be included in engineering education. One is on whether it should be as separate courses or integrated into the technical curriculum. In a paper 
discussing just this, Herkert [5] argue that ethics taught as a separate course is challenging both to economy and organisation of the educational programme (due to already tight schedule) - and even more important: it "can leave the students with the impression that ethics is a sidebar rather than an integral part of their engineering studies". This corresponds to our own experience.

The next discussion is on how ethical competence is best trained. A question before this is what is meant by the term ethical competence. In an investigation from Finland, Kulju et al. [6] discuss the concept of ethical competence. They conclude that ethical competence "is a personal capacity including ethical awareness, courage, willingness, and skills in decision-making and ethical action". How, then, is this personal capacity best developed?

Harris et al. [3] claim that "There is widespread agreement that the best way to teach professional ethics is by using cases". Being challenged through exercises on cases seems a reasonable approach to gaining ethical ballast when defining ethical competence through concepts as awareness, courage, willingness, and skills. These concepts are all highly personal and can hardly be obtained through listening to lectures or reading books alone. Harris et al. [3] also refer to results from a gathering of educators from a broad range of disciplines, organised by the New York think tank The Hastings Centre: "One goal they identified was to stimulate the ethical imagination of students. Too often, the educators agreed, young professionals get caught by surprise when faced with an ethical problem in their professional practice. Never having seriously thought about such a problem, they may not handle it well."

\section{1 Integrating ethical cases in technical curricula}

Cases suitable for such exercises should be easily available in all local environments. At our university, we are presently working in close cooperation with the industry to identify opportunistic behaviour and revealing deconstructive mechanisms causing legal actions between contractors and building clients in large construction projects. This is a common problem, gaining nobody except lawyers. Engineers are present at both sides in these conflicts, illustrating the actuality of the problem. However, also simple examples seem easily available in subjects often claimed to be purely technical; consequences for operational costs from the choice of building materials - and the engineer's obligation to inform the building client about this. Another example is flexibility for the future use of a building, given from choice of the structural system in the design process.

Harris et al. [3] present two methods for working with ethical discussions. One is "drawing the line": Identifying situations where an engineer is exposed to a unethical situation is easy - e.g., where he or she is offered a substantial bribe to prefer one special solution or product. The opposite is also easy; identifying situations where an offer is of value negligible to influence any decision - for instance, a commercial plastic pen. Interesting for developing the ethical ballast of students (or anyone), is to discuss where the line is to be drawn between these two situations. This discussion will have to include identifying similarities and differences between acceptable and un-acceptable situations.

The other method is to decide in a conflicting situation. This might be a situation where the engineer is in a personal conflict of interests, e.g., when having to choose whether or not to inform the client of an issue when it might have negative influence for his or her employment. Or it might be a situation where the choice is mutually exclusive to two positive interests.

"Drawing the line" and "choosing in conflicting situations" are only two methods exemplifying easily available pics, from the pedagogical toolbox that surely offers far more methods for developing ethical ballast of (young) engineers.

\section{CONCLUSIONS}

1. To fulfil its societal responsibility (regarding engineering education), universities need to educate engineers in skills on how to execute the profession, in addition to the technical skills.

2. These additional skills are needed for ballast, to prepare the engineers on situations they will frequently meet in working life, where they must execute value judgments.

3. The ballast needed by professionals for executing value judgments, is based on ethics. Hence, students need to acquire knowledge and skills on the "professional ethics of engineering".

4. The professional ethics of engineering is partly codified (through regulations, acts, and standards), partly existing only as tacit knowledge amongst practitioners.

5. Engineering societies offers professional codes of conduct that can act as guidelines for the development of the required professional ballast. Even if engineering societies tend to be national, these professional codes seem to be closely related. 
6. To avoid giving the students the impression that ethics is a sidebar rather than an integral part of their engineering studies, education on ethics should be integrated into technical subjects.

7. The ethical ballast or competence that is to be developed amongst engineering students might be defined in terms like personal capacity, including ethical awareness, courage, willingness, and skills in decision-making and ethical action.

8. Such highly personal competence seems best developed through working with cases illustrating different dilemmas, where students have to choose a side and argue for the choices.

9. Several methods are available for working with ethical dilemmas through cases, for instance, "line drawing" and "choosing in conflicting situations".

\section{REFERENCES}

[1] Thorstensen R.T., Svennevig P.R. and Larsen I.L. Societal responsibility in Engineering Education; a case study on R\&DI cooperation within civil engineering. in The 20th International Conference on Engineering and Product Design Education (E\&PDE 2018). 2018. Dyson School of Engineering, Imperial College, London.: The Design Society.

[2] Bucciarelli L.L.J.E.J.o.E.E. Ethics and engineering education. European Journal of Engineering Education, 2008. 33(2): p. 141-149.

[3] Harris Jr C.E. et al. Engineering ethics: what? why? how? and when? Journal of engineering education, 1996. 85(2): p. 93-96.

[4] McGinn R.E.J.S. and Ethics E. "Mind the gaps": An empirical approach to engineering ethics, 1997-2001. Science and engineering ethics, 2003. 9(4): p. 517-542.

[5] Herkert J.R.J.E.j.o.e.e., Engineering ethics education in the USA: Content, pedagogy and curriculum. European Journal of Engineering Education, 2000. 25(4): p. 303-313.

[6] Kulju K. et al. Ethical competence: A concept analysis. Nursing ethics, 2016. 23(4): p. 401-412. 